\title{
Peer to Peer Synchronous Interaction and Student Engagement: A Perspective of Postgraduate Management Students in a Developing Country
}

\author{
Nazlee Siddiqui ${ }^{1, *}$, Khasro Miah $^{2}$, Afreen Ahmad ${ }^{3}$ \\ ${ }^{1}$ Tasmanian School of Business and Economics, University of Tasmania, Sydney, Australia \\ ${ }^{2}$ School of Business and Economics, North South University, Dhaka, Bangladesh \\ ${ }^{3}$ Southeast Business School, Southeast University, Dhaka, Bangladesh \\ *Corresponding author: Nazlee.siddiqui@utas.edu.au
}

Received May 04, 2019; Revised June 18, 2019; Accepted July 10, 2019

\begin{abstract}
The purpose of this study is to investigate the association between synchronous peer to peer interaction (PPSI) and student engagement in postgraduate management units in Bangladesh. Understanding of this association focused on outcomes of engagement with learning materials and workplace relevant learning. This study utilized an interventional and convergent parallel mixed methods research design. A PPSI intervention, involving teamwork of five students from working and non-working status, was applied on 80 students in two different management units. The intervention was followed by a survey on student's perception of the association between PPSI and student engagement, which received $80 \%$ response rate. Content analysis was applied to the qualitative survey data while quantitative data were analyzed with SPSS software. Participant profile were $60 \%$ female, $95 \%$ below the age of 30 and $71 \%$ having work experience. The study found a significant positive association $(\mathrm{r}=.53)$ between PPSI and student engagement in postgraduate management study in Bangladesh. Peer to peer interaction helped students to collect different viewpoints, engage with learning material and practice workplace relevant skills. However, success of PPSI is influenced by factors such as task design, student's attitude toward teamwork and ease of use of technology. This study is first of its kind to explore the in-depth relationship between PPSI and student engagement in an education setting in a developing country. It could open avenues for further research on designing and implementation of PPSI for student centered and work relevant learning, across developed and developing countries.
\end{abstract}

Keywords: peer to peer, synchronous interaction, student engagement, workplace relevant learning, engagement with learning materials

Cite This Article: Nazlee Siddiqui, Khasro Miah, and Afreen Ahmad, "Peer to Peer Synchronous Interaction and Student Engagement: A Perspective of Postgraduate Management Students in a Developing Country." American Journal of Educational Research, vol. 7, no. 7 (2019): 491-498. doi: 10.12691/education-7-7-9.

\section{Introduction}

Synchronous peer to peer interaction (PPSI) refers to a negotiated environment where students work collaboratively in real-time, either in one to one or small groups $[1,2]$. PPSI is sometimes studied as an exclusive online collaboration mechanism [3], but in this investigation, PPSI covers real-time interactions through face to face, text, audio, and online medium [4]. Students experiencing PPSI can achieve quality learning, through different actions such as helping each other in completion of assigned work and challenging each other's knowledge in open and comfortable peer interactions [5,6,7]. Some of the other benefits of PPSI are better course completion rate $[8,9]$, more wonderful community feeling between students [10], and lower burn-out rate for online teachers [11]. While technical glitches [12,13] and difficulties in scheduling the interaction [12] are some hurdles in PPSI, students report the overall experience of PPSI is still productive $[12,13]$. PPSI is thus an avenue for active and collaborative student engagement, which is considered an advantageous attribute for quality education and success in higher studies $[6,7,14]$. However, current literature on this topic is skewed towards evidence from education settings in a developed country. Whereas, the mechanisms of student engagement is believed to be different across different country settings [15]. Given the ongoing growth of innovative learning such as blended and MOOC (massive open online education) in South Asian universities [16], this is an appropriate time to apprehend potential of PPSI in this educational setting.

This study investigates the premises of associations between PPSI and student engagement in postgraduate (Master level course) management units in Bangladesh. This South Asian developing country has advanced in the digital economy [17] and intending better integration of technology for interactive and contemporary skill-oriented higher education [18]. The focus of this study is on peer 
interaction for outcomes of engagement with learning materials and workplace relevant learning. These outcomes and PPSI should be interdependent, respectively, falling into three domains of student engagement in higher education: academic, cognitive, and social engagement with peers $[19,20]$. Hence, understanding of the association between these concepts is critical to the functioning of student engagement in postgraduate education.

\subsection{Research Questions}

This study addresses the following four research questions from the perception of students:

- Is PPSI associated with student's engagement with learning materials and thinking of applying classroom learning to workplace scenarios?

- How can PPSI be associated with student's engagement with learning materials?

- How can PPSI be associated with student's engagement with thinking of applying classroom learning to workplace scenarios?

- What are the critical factors in PPSI that can facilitate student engagement?

\section{Conceptual Framework}

Student engagement is recognized to facilitate studentcentered education in various ways: it protects students from the risk of failure in learning [20], enhances student's academic achievement and satisfaction [21] and provides students with life-long learning capacity [22]. Multifaceted factors work together to shape the concept of student engagement $[14,20]$. Moreover, the conceptualization of student engagement can differ between higher education versus other educational levels [19]. The five inter-related factors of student engagement in higher education are: 1) Academic Engagement, including behavior of learning such as engagement with or spending time to read the learning materials, (2) Cognitive Engagement, covering psychological investment for complicated learning such as thinking of applying classroom learning to work scenarios (3) Social Engagement with Peers, comprising of interaction of support with peers such as cooperation in team assignments (4) Social Engagement with teachers, encompassing interaction of guidance such as teachers lecturing in online class and (5) Affective Engagement, consisting of emotional involvement such as student's bonding with the identify of their education institute. This five-factor model [19] supports the theorization of associations between PPSI and student engagement with learning materials and work relevant learning, as proposed in this study. This study investigates the three factors in the model: academic engagement, cognitive engagement, and social engagement with peers.

Furthermore, PPSI can facilitate student engagement in line with the theory of social-constructivism professed by Lev. Vygotsky [7,23,24]. Social constructivism propagates collaborative learning, a process where students achieve deeper learning through different actions such as helping each other in completion of assigned work and challenging each other's knowledge in open and comfortable peer interactions [7]. PPSI, equipped with the features of peer exchange of immediate feedback and ideas, facilitates social constructivism. This results in students developing a better understanding of the course content [25] and experiencing success in the achievement of team goals [12]. Few researchers [13,26,27] explained PPSI has to incorporate the right task, possessing attributes such as critical thinking, clear relevance to student's topic of learning and subjective interpretations as opposed to correct standardized answer. Researchers [28,29] further clarified that PPSIs are beneficial for interprofessional discourse, which is a desirable attribute for management education and works as well. Therefore, investigating the association between PPSI and student engagement is a conceptually sound initiative for scholarship of teaching and learning in postgraduate management study.

\section{Enhancing Higher Education in Bangladesh}

Higher education is essential for human capital and overall economic development in Bangladesh [30]. Postgraduate management study, the master level management major degrees at university, contributes to higher education and associated developments in the country. Bangladesh has an expanding higher education market, consisting of 103 private universities, 45 public universities, and three international universities [31]. Postgraduate management education is a common offering across the public, private, and international universities.

There is scope for improving quality in higher education in Bangladesh, with a prominent issue being graduates lacking adequate workplace-relevant skills [32]. In a recent study on higher education in Bangladesh [33], both employers and students were reported to value teambuilding capability as an employability skill. In the same study, employers in Bangladesh showed priority for subject knowledge, breadth of knowledge, and application of knowledge. These are evidence for the contextual need for teaching and learning interventions that attend to employability skills, including team-work, knowledge acquisition, and application of knowledge. This investigation on PPSI's association with student's engagement with learning materials can address the required knowledge acquisition skills. The investigation also impacts employability skills, more broadly, assessing the association between PPSI and student's cognition for applying classroom learning to the workplace scenarios.

Synchronous education, through face to face interaction, is the prominent mode of learning in higher education in Bangladesh. About two open universities in Bangladesh offer technology-based synchronous education, in a limited manner, through internet and interactive audio and video sessions [34]. Till now, most universities do not have their online learning platforms such as Moodle and Blackboard that are common in developed country education settling. However, the potential for wider use of technology-based synchronous learning is apparent, with private university students becoming users of real-time blogs, mobile texts, online discussion boards (Skype), Flickr, YouTube, Facebook, etc. [35]. In light of the advancement of the digital economy in the country [17], there is a growing interest to integrate technology in 
education sector [18]. Technology-based synchronous learning could make higher education in Bangladesh accessible to a wider community, negotiating travel difficulties, and social conservatism against women education [36]. These factors endorse this investigation on synchronous interaction in postgraduate management study to be a philanthropic initiative.

\section{Methods}

This investigation was conducted with students who were studying in two management units in a postgraduate program in a private university in Bangladesh. During the data collection time, in the 2018 fall semester, 80 students were enrolled in these units combined. These two units cover more than $10 \%$ of the annual enrollment of management students in the program. This study utilized an interventional and convergent parallel mixed methods research design [37]. The following section describes the research design, including the teaching intervention and survey tool.

\subsection{Research Design}

The intervention of teaching practice was drawn from extensive consultation between the chief investigator, who taught at a university in Australia and the two co-investigators, who taught at two different universities in Bangladesh. One of the co-investigators taught at the university where the research was conducted. The consultation started with the chief investigator presenting a PPSI teaching practice that received positive feedback from Australian students. This initial PPSI teaching practice was changed to fit the research context, as advised by the two co-investigators.

In its final form, the PPSI intervention involved the work of a team of 5 students. The unit coordinator, one of the co-investigators, had arranged the teams with a combination of working and non-working students. Investigators believed such a mix of students in the team would be conducive to the research aim about reflection on work relevant learning. Each team had to make two submissions in this PPSI intervention: one, a 350-400 words answer to a question that students write as a team in synchronous mode (online/audio discussion in real time). This question required the team to identify relevant reading materials of the course and an example of applying the learning from the readings in managing a realistic workplace scenario. This short answer task intended students to collaborate for critical thinking and succinct writing. Two, an online/audio team discussion (maximum 6 minutes) as a sample of their synchronous collaboration. These submissions were made two weeks before the four-month teaching session ended. The PPSI intervention carried $5 \%$ weighting in the unit's marking. The unit coordinator briefed students of the marking rubric, which had specific criteria regarding evidence of collating ideas from different team members.

A survey was applied, collecting quantitative and qualitative data simultaneously. This survey had two items to capture student's perception of an association between their experience of PPSI and student engagement. One, whether the PPSI had induced engagement with learning materials. Two, whether the PPSI induced engagement with thinking of applying classroom learning to workplace scenarios. These items were of Likert scales of 1 to 5 . On this scale, 5 corresponded to Strongly Agree, 4 to Agree, 3 to Neutral, 2 to Disagree and 1 to Strongly Disagree. These two items had corresponding free-text (qualitative) answer options where participants provided comments, explaining the rationale of PPSI impacting student engagement. Furthermore, the survey covered a question to collect student's suggestions to improve the PPSI for a better learning experience. This was a qualitative question, requiring students to respond with comments in free-text.

\subsection{Ethical Considerations}

Investigators acknowledge that students participating in this study can have an unequal relationship with one of the co-investigators. Given that one of the co-investigators was the unit coordinator of the units where research participants were studying. Investigators have collected data from students in a voluntary and anonymous survey, mitigating risks of such unequal relationship biasing the research findings. There is no ethical review process in practice, by which this study could receive a formal ethical clearance in Bangladesh. Investigators consulted the study with the appropriate authority in the research context, that is, the postgraduate program director of the university. The investigators followed a research process that was similar to the approved protocol of the Australian PPSI (reference number H0015793 with the human research ethics committee at the University of Tasmania). Moreover, throughout the research, investigators were respectful to all those who were involved in this inquiry. For example, the PPSI intervention was not onerous on students and the survey was conducted online to ensure the privacy and confidentiality of the student participants.

\subsection{Survey Procedure and Participants}

All enrolled students of the chosen units were invited to participate in the survey via an announcement on the university's website. One of the co-investigators, who did not teach at the research context, was in charge of the survey data collection. She conducted the survey online, via survey monkey. A total of 65 completed surveys were submitted, corresponding to $80 \%$ response rate. Table 1 describes the profile of the survey participants, by age, gender, and work and study conditions.

Table 1. Profile of student participants in the study

\begin{tabular}{|l|l|l|}
\hline Characteristics & Categories & $\mathrm{N}(\%)$ \\
\hline \multirow{4}{*}{ Age } & 30 years or below & $60(95)$ \\
\cline { 2 - 3 } & Above 30 years & $3(5)$ \\
\cline { 2 - 3 } Gender & Missing Response & 2 \\
\hline \multirow{3}{*}{$\begin{array}{l}\text { Students with work } \\
\text { experience }\end{array}$} & Female & $38(60)$ \\
\cline { 2 - 3 } & Male & $25(40)$ \\
\cline { 2 - 3 } & Missing Response & 2 \\
\hline \multirow{2}{*}{$\begin{array}{l}\text { Students working and } \\
\text { studying simultaneously }\end{array}$} & Yes & $46(71)$ \\
\cline { 2 - 3 } & No & $19(29)$ \\
\cline { 2 - 3 } & Missing Response & None \\
\cline { 2 - 3 } & No & $23(38)$ \\
\cline { 2 - 3 } & Missing Response & $57(62)$ \\
\hline
\end{tabular}




\subsection{Data Analysis}

Quantitative data were analyzed with descriptive statistics and correlation coefficient. In some analysis, a record was excluded if the specific data item was missing. Hence, there is slight variability in the numbers across the analysis undertaken. First, a profile analysis of the participants included percentage breakdown regarding: age, gender, work, and study conditions (Table 1). Second, Current study assessed the effect of PPSI on the two types of student engagement via mean and percentage analyses (Table 2). Mean values beyond the neutral point and high percentages at the levels of "Strongly Agree" and "Agree" indicated a positive effect of PPSI on student engagement. Finally, Pearson correlation analysis was conducted to assess an association between the two types of student engagement. Which are one, PPSI induced engagement with learning material and two, PPSI induced engagement with thinking of applying classroom learning to workplace scenarios? The association can be assessed as low, moderate, and high in cases where the value of coefficient correlation $(\mathrm{r})$ is below 0.3 , between 0.3 to below 0.5 and above 0.5 respectively [38].

Content analysis was applied on the qualitative survey data. The analysis went through the three stages: preparing, organizing and reporting $[39,40]$. In the preparation stage, investigators jointly identified the unit of analysis as a survey respondent's answer to the free-text questions regarding the PPSI's influence on student engagement and suggestions of improving the PPSI. At this stage, it was also decided to draw manifest rather than the underlying meaning of data [40]. During the stage of organization, a deductive approach was taken to compare the qualitative responses against the four research questions in the study. The process involved each of the three investigators individually analyzing the content of the qualitative responses according to the research questions. This process progressed to independent initial coding of the content, noting the frequency of the codes and identifying associated quotations in the categorization matrix. This categorization matrix, including the initial codes and supporting quotations, was finalized in joint discussions between the investigators. The finalized codes, with an example, quotations, organized around the research questions, have been reported in Table 3, 4, and 5. It is understood that the sessions of joint discussions between the investigators mitigated possible researcher biases through conformability [39].

\section{Results}

This section presents the survey result, the quantitative and qualitative responses, answering the research questions in this study.

\subsection{Association between PPSI and Student Engagement}

Students responded positively to the research question, "Is PPSI associated with student's engagement with learning materials and thinking of applying classroom learning to workplace scenarios?" This is evidenced by about $97 \%$ of students either agreeing or strongly agreeing that PPSI enhanced their engagement with two items in Table 2. One, PPSI induced engagement with learning materials and two, PPSI induced engagement with thinking of applying classroom learning to workplace scenarios (Frequency row, Table 2). This positive notion is further endorsed, with mean values of 4.40 (SD: 0.68), on PPSI induced engagement with reading materials, and 4.45 (SD: 0.69), on PPSI induced engagement with thinking of applying classroom learning to the workplace (Mean row, Table 2). Correlation $(\mathrm{r}=.53)$ between these constructs were significant and had a substantial effect [38]. Styles for table title, table head, and table text are provided. Tables should be set in one column wherever possible and be placed near their first mention in the body. Tables and figures do not need to be placed on separate pages at the back of the manuscript.

Similarly, few survey comments indicated a positive association between PPSI induced engagement with reading materials and workplace relevant learning. Four students had made comments with such a notion. The following comment from a student is placed to reflect this notion:

"Online collaboration with peers enabled me to have a better idea about various sections of my reading materials. Through this, I can know which parts of my reading materials can be applied to my work problems (Respondent \# 47)."

Table 2. PPSI induced student engagement with learning materials and workplace relevant cognition

\begin{tabular}{|c|c|c|c|}
\hline \multirow{2}{*}{ Status of Student Engagement after the PPSI experience } & \multirow{2}{*}{ Descriptive Statistics } & \multicolumn{2}{|c|}{ Correlation Coefficient (r) } \\
\hline & & 1 & 2 \\
\hline \multirow{3}{*}{ 1. PPSI induced engagement with learning materials } & Mean $(\mathrm{SD})=4.40(0.68)$ & \multirow{3}{*}{1} & \multirow{3}{*}{.530} \\
\hline & $\begin{array}{l}\text { Frequency: N }(\%) \\
1(1.6)=\text { Strongly Disagree } \\
1(1.6)=\text { Neutral } \\
33(50.8)=\text { Agree } \\
30(46.2)=\text { Strongly Agree }\end{array}$ & & \\
\hline & $\mathrm{N}=65 ;$ Missing value $=$ none & & \\
\hline \multirow{3}{*}{$\begin{array}{l}\text { 2. PPSI induced engagement with thinking of applying } \\
\text { class-room learning to workplace scenarios }\end{array}$} & Mean $(\mathrm{SD})=4.45(0.69)$ & \multirow{3}{*}{.530} & \multirow{3}{*}{1} \\
\hline & $\begin{array}{l}\text { Frequency: N }(\%) \\
1(1.5)=\text { Strongly Disagree } \\
1(1.5)=\text { Neutral } \\
29(45.3)=\text { Agree } \\
33(51.6)=\text { Strongly Agree }\end{array}$ & & \\
\hline & $\mathrm{N}=64 ;$ Missing value $=1$ & & \\
\hline
\end{tabular}

Note: Correlation is significant at the $\mathrm{p}<0.01$ level (2-tailed); $\mathrm{SD}=$ Standard Deviation. 


\subsection{Rationale for Student Engagement with Learning Materials}

Table 3 presents the result of the content analysis for the research question "How PPSI can be associated with student's engagement with learning materials?" In this study, students perceived PPSI to be a practice where peers motivated each other to be oriented to the learning materials. The most common mechanism of this motivation was peers discussing the learning materials from different viewpoints. As the quotation from the respondents (Row 1, Column 3, and Table 3) indicates, exposure to peer's variety of opinions had helped students to understand the reading materials in greater depth. The other mechanisms of positive association were sharing of the reading load with peers, collaborative unpacking of the problematic concepts and intention for valuable online experience with peers. Only about $5 \%$ of students found the PPSI to have a neutral impact on their engagement with learning materials. One student had identified the inadequate duration of PPSI for the neutrality. Other students did not clarify why they found PPSI ineffective in influencing their engagement with learning materials.

\subsection{Rationale for Student Engagement with Workplace Relevant Cognition}

Table 4 presents the result of the content analysis for the research question "How PPSI can be associated with student's engagement with thinking of applying to learn to workplace scenarios?" In this study, majority of students perceived PPSI is facilitating the application of learning to workplace scenarios, as PPSI provided an opportunity to practice work-relevant skills such as managing teams, communication, and individual strengths and weaknesses (Row 1, Column 3, Table 4). Some students had the notion that the PPSI environment was similar to that at work as they interacted with peers who were working and collaboratively worked towards the same goal and practical solutions (Row 2, Column 3, Table 4). It was also noted that working students, as opposed to non-working, could find it easier to think about applying classroom learning to work (Row 3, Column 3, Table 4).

Table 3. Content analysis of engagement with learning materials

\begin{tabular}{|l|l|l|}
\hline Codes & Frequency (\%) & Example quotations \\
\hline $\begin{array}{l}\text { Peers shared different viewpoints of } \\
\text { the learning materials. }\end{array}$ & $\begin{array}{l}\text { "Online collaboration that I experienced with my peers gave me the opportunity to } \\
\text { brainstorming different viewpoints of the readings and learn more effectively from the } \\
\text { different viewpoints (Respondent \# 59)". } \\
\text { "Peers different point of views made the readings interesting (Respondent \# 30)". } \\
\text { "We learnt many new things as each of us shared understanding of the readings and the } \\
\text { management theories (Respondent \# 18)". }\end{array}$ \\
\hline $\begin{array}{l}\text { Peers shared the reading load and } \\
\text { quickly taught each other the } \\
\text { learning materials. }\end{array}$ & $\begin{array}{l}\text { "I believe group study or peer interaction helps us to quickly grasp the readings, as we could } \\
\text { share the readings and teach each other what we read online. Particularly, in last minute } \\
\text { preparation, there is nothing to beat the advantages of online collaboration (Respondent \# } \\
40) \text { ". }\end{array}$ \\
\hline $\begin{array}{l}\text { Peers encouraged being oriented } \\
\text { with the readings and collaboratively } \\
\text { solved the difficult concepts. }\end{array}$ & $11(17)$ & $\begin{array}{l}\text { "My peers encouraged me to read the learning materials and together we solved the difficult } \\
\text { concepts (Respondent \# 65)". }\end{array}$ \\
\hline $\begin{array}{l}\text { Students read learning materials for } \\
\text { constructive online experience with } \\
\text { peers. }\end{array}$ & $9(14)$ & $\begin{array}{l}\text { "For the online experience with peers to be constructive I went through the topics first to } \\
\text { identify the points of discussion with my team members. This resulted in more than usual } \\
\text { engagement with the reading materials and a better retention of learning (Respondent \# 46)". }\end{array}$ \\
\hline $\begin{array}{l}\text { Student's engagement with learning } \\
\text { materials was neutral. }\end{array}$ & $3(5)$ & $\begin{array}{l}\text { "I believe the peer interaction was too short and had neutral impact on my readings } \\
\text { (Respondent \# 50)'. }\end{array}$ \\
\hline Total & $64(100)$ &
\end{tabular}

Note: One survey respondent did not make any comment on the topic.

Table 4. Content analysis of workplace relevant cognition

\begin{tabular}{|c|c|c|}
\hline Codes & Frequency $(\%)$ & Example quotations \\
\hline $\begin{array}{l}\text { PPSI gave them scope to } \\
\text { practice work relevant skills. }\end{array}$ & $42(66)$ & $\begin{array}{l}\text { "It helped me to increase skills for my work by learning how to manage a group to be efficient and } \\
\text { complete the work timely. I can apply the same approach with which I maintained coordination in } \\
\text { this peer interaction (Respondent \# 22)". } \\
\text { "In our workplace we have to communicate with lots of people. In this team work, we had lots of } \\
\text { communication with peers. So, this is very helpful for us (Respondent \# 17)." } \\
\text { "Group discussion helped me to develop many transferable skills like team work, leadership which } \\
\text { we will be able to apply to our workplace (Respondent 18)." } \\
\text { "In workplace it is very important to know individual strength and weakness. We also learnt that } \\
\text { skill in this online work (Respondent 24)." }\end{array}$ \\
\hline $\begin{array}{l}\text { PPSI created an environment } \\
\text { that is similar to workplace } \\
\text { scenarios. }\end{array}$ & $15(23)$ & $\begin{array}{l}\text { "Each and every activity was helpful. Because we could get to know about job experiences of } \\
\text { others. It was also very fun (Respondent } 42 \text { )." } \\
\text { "Here we worked towards the same goal as the case at work. Also, it was difficult to work with } \\
\text { unknown people but that happens at work too (Respondent \# 28). " } \\
\text { "There are many issues for which there are no solutions in the book. Peer interaction helped to talk } \\
\text { about these issues and find practical solutions just like what I do at work (Respondent \# 65)." }\end{array}$ \\
\hline $\begin{array}{l}\text { PPSI association to } \\
\text { engagement varied, } \\
\text { depending on whether they } \\
\text { were working or not. }\end{array}$ & $7(11)$ & $\begin{array}{l}\text { "Since I am working in corporate environment, it definitely helped me to think that I should } \\
\text { implement these theories in my workplace (Respondent \# 33)." } \\
\text { "Right now, I am not working But I feel that I have learned so many things in this collaboration. } \\
\text { These will help me in my future workplace (Respondent \# 41)." }\end{array}$ \\
\hline Total & $64(100)$ & \\
\hline
\end{tabular}

Note: One survey respondent did not make any comment on the topic. 
Table 5. Content analysis of critical factors in PPSI

\begin{tabular}{|c|c|c|}
\hline Codes & Frequency $(\%)$ & Example quotations \\
\hline $\begin{array}{l}\text { Students should find the task in PPSI } \\
\text { meaningful }\end{array}$ & $30(46)$ & $\begin{array}{l}\text { "The written task and online collaboration needed information about the readings and } \\
\text { explanation of how these readings can manage workplace scenarios. So, I went through the } \\
\text { reading materials over and over again and applied the learning to the project scenarios at } \\
\text { work (Respondent \# 20)." } \\
\text { The required topic had me thinking about the chapters taught in the class and connect the } \\
\text { learning to what happens at work. Some of us had to go through the chapters again and } \\
\text { rethink about our work and this involved critical thinking (Respondent \# 55)". } \\
\text { "Interacting with peers was important as our grade depended on it (Respondent \# 11)". }\end{array}$ \\
\hline $\begin{array}{l}\text { Students should find the } \\
\text { tool/technology of PPSI to be } \\
\text { convenient }\end{array}$ & $19(29)$ & $\begin{array}{l}\text { "Online collaboration via Facebook or iPhone makes it easy to communicate properly. } \\
\text { Within real time I could get help from peers (Respondent \# 37)". } \\
\text { "Usually, when studying in teams it is tough to meet as a team. We are not able to meet } \\
\text { each other as we have different work hours and other commitments. Because of online } \\
\text { (Skype) collaboration, it become easy to meet as a team and it saved time from travelling } \\
\text { (Respondent \# 45)". } \\
\text { "Skype, Facebook services are often not working here. We faced this problem and } \\
\text { completed the task with group messaging and audio recording on phone (Respondent \# } \\
\text { 46)." }\end{array}$ \\
\hline $\begin{array}{l}\text { PPSI's facilitation of student } \\
\text { engagement is dependent on attitude } \\
\text { of team members. }\end{array}$ & $12(19)$ & $\begin{array}{l}\text { Some members in my team had the wrong attitude. They were focused on getting things } \\
\text { done by other members rather than themselves. While we completed the task on-time, I } \\
\text { have less enthusiasm for peer interactions (Respondent \# 51). } \\
\text { My team members despite working full time and also doing masters full time managed to } \\
\text { match time with others and collaboratively completed the work. It was not an easy task, } \\
\text { but we did it because we were committed (Respondent \# 62). }\end{array}$ \\
\hline $\begin{array}{l}\text { PPSI's facilitation of student } \\
\text { engagement can be better, if adequate } \\
\text { time is provided for students to } \\
\text { practice PPSI. }\end{array}$ & $4(6)$ & $\begin{array}{l}\text { There should be more time for students to practice PPSI...That way, we could engage in } \\
\text { this process more frequently and naturally (Respondent \#3). }\end{array}$ \\
\hline Total & 65 & \\
\hline
\end{tabular}

\subsection{Critical Rationale in PPSI for Student Engagement}

Table 5 presents the result of the content analysis for the research question "What are the critical factors in PPSI that can facilitate student engagement?" Majority of students commented about how PPSI was made meaningful to them through a task design that required as follows: specific information from the readings; collaborative thinking of the readings and rethinking of the work scenarios (Row 1, Column 3, and Table 5). Moreover, students were motivated to engage in the PPSI tasks, as it impacted their grade (Row 1, Column 3, and Table 5). Other factors that were critical for students to be involved in PPSI are provided in Rows 2, 3, and 4 of Table 5. It is seen that while students found the use of technology for real-time communication beneficial, they also had to manage the inconvenience of switching between technologies due to technical disruption. A positive attitude from team members that exhibits a commitment to teamwork was seen as necessary for students to be enthusiastic for PPSI. Lastly, few students commented on the criticality of practising PPSI and requiring adequate time to do so.

\section{Discussion}

This study has provided empirical evidence of a positive association between PPSI and student engagement in postgraduate management study in Bangladesh. The evidence came from students and clarified the functioning of student engagement through three specific mechanisms: PPSI, a social engagement; learning of reading materials, an academic engagement; and thinking of applying classroom learning to workplace scenarios, a cognitive engagement $[19,20]$. To the best of the authors' knowledge, this is unique work on PPSI, providing an in-depth explanation of the association between peer to peer interaction and student engagement in an education setting in a developing country. The finding of this study conforms to the theory social-constructivism [7,23,24], in its depiction of how real-time interactions with peers allowed practical problem solving and learning of reading materials in team assessment. Peers encouraging each other highlight potential for academics to use PPSI for countering student's minimalist approach with reading learning materials [41]. Moreover, peer to peer interaction provided an avenue for students to practice workplace-relevant skills such as team-building capability [33]. Additionally, this study endorsed interrelation between PPSI induced student's engagement with reading materials and workplace relevant learning. This implies that academics will be rewarded with a stronger enhancement of student engagement when delivering teaching interventions that facilitate both academic learning and workplace relevant cognition. Given that employers in Bangladesh are looking for subject knowledge as well as knowledge application $[31,33]$, this type of teaching intervention is necessary to improve quality in higher education.

The linkage between PPSI and student engagement is not an automatic phenomenon, however. Academics will need to invest substantial time [27,42], incorporating certain critical factors in PPSI to materialize this linkage. One such critical factor is designing of tasks where features of collaboration, immediate exchange of ideas, and critical analysis are inherent [7,23,24]. For instance, the PPSI task in this study required students to critically reflect on specific readings and example of applying the learning to workplace scenarios. Moreover, students had to provide evidence of collating views of different team 
members. Individual team member's skills [7], that is, the experience of workplace scenarios in this study, and attitude towards teamwork [43] were critical for the success of PPSI. Academic's involvement in forming teams with working and non-working students evidenced success in managing some of these factors in this study. Academics may also need to coach students with collaboration skills if substantial lacking exists in this area. Ease of use of technology for real-time communication came across as another critical factor for PPSI [13]. Despite the advancement in digital technologies [17], social networking tools such as Skype and Facebook failed to provide consistent technical support for PPSI in this study. This implies that PPSI in a developing country should allow the use of a combination of face to face, text, audio, and online mediums. Another insight from this study is that students require practice and time to develop skills for PPSI. Future studies should explore the effective designing of PPSI within the short teaching session such as four months, which was the case for this study.

\section{Conclusion}

PPSI can be an avenue for enhanced student engagement in higher education in a developing country. Successful incorporation of PPSI in the study requires an investment of more time and effort from both the academics and students. Drawing on the insights from this study, PPSI comes across a worthwhile investment in pursuit of quality higher education.

\section{References}

[1] Anthony SC. Synchronous and Asynchronous Interactions: Convenience and Content. In: Ari S, editor. Advancing Library Education: Technological Innovation and Instructional Design. Hershey, PA, USA: IGI Global; 2013. p. 127-40.

[2] Oztok M, Zingaro D, Brett C, Hewitt J. Exploring asynchronous and synchronous tool use in online courses. Computers \& Education. 2013; 60(1): 87-94.

[3] Cherney MR, Fetherston M, Johnson LJ. Online Course Student Collaboration Literature: A Review and Critique. Small Group Research. 2017; 49(1):98-128.

[4] Cook M, Dickerson DL, Annetta LA, Minogue J. IN-SERVICE TEACHERS' PERCEPTIONS OF ONLINE LEARNING ENVIRONMENTS. Quarterly Review of Distance Education. 2011; 12(2): 73-9.

[5] Bower M, Kenney J, Dalgarno B, Lee M, Kennedy G. Blended synchronous learning: Patterns and principles for simultaneously engaging co-located and distributed learners. 30th Ascilite Conference Macquarie University, Sydney 2013.

[6] Cunningham U. Teaching the disembodied: Othering and activity systems in a blended synchronous learning situation. 2014. 2014; 15(6).

[7] Powell KC, Kalina CJ. Cognitive and Social Constructivism: Developing Tools for an Effective Classroom. Education. 2009; 130(2): 241-50.

[8] Norberg A. Blended Learning and New Education Logistics in Northern Sweden. In: Oblinger D, editor. Game Changers: Education and information technologies. 1st ed: Boulder: Educause Publications; 2012. p. 327-30.

[9] Power M. The Emergence of a Blended Online Learning Environment. MERLOT Journal of Online Learning and Teaching 2008; 4(4):503-14.

[10] Reese SA. Online learning environments in higher education: Connectivism vs. dissociation. Education and Information Technologies. 2014; 20(3): 579-88.
[11] McCann J, Holt R. An Exploration of Burnout Among Online University Professors. JOURNAL OF DISTANCE EDUCATION. 2009; 23(3): 97-110.

[12] Maushak NJ, Ou C. USING SYNCHRONOUS COMMUNICATION TO FACILITATE GRADUATE STUDENTS' ONLINE COLLABORATION. Quarterly Review of Distance Education. 2007; 8(2): 161-9.

[13] Holzweiss PC, Joyner SA, Fuller MB, Henderson S, Young R. Online graduate students' perceptions of best learning experiences. Distance Education. 2014; 35(3): 311-23.

[14] Kahu ER, Nelson K. Student engagement in the educational interface: understanding the mechanisms of student success. Higher Education Research \& Development. 2018; 37(1): 58-71.

[15] Tanaka M. The international diversity of student engagement. In: Tanaka M, editor. Student Engagement and Quality Assurance in Higher Education. 1st edition. London: Rutledge; 2019.

[16] Economist Intelligence Unit Limited. Connecting universities: Future models of higher education. Analyzing innovative models for Afghanistan, Bangladesh, India, Nepal, Pakistan, and Sri Lanka. British Council; 2015.

[17] Botticello C. Technology sector makes unprecedented progress. Beaming Bangladesh: A magazine of the Embassy of Bangladesh. 2019:24-5.

[18] Mahmuda M. Teaching and Learning Through Technology In Bangladesh Higher Education. International Journal of Scientific \& Engineering Research. 2016; 7(4)

[19] Zhoc K, Webster B, King R, Li J, Chung T. Higher Education Student Engagement Scale (HESES): Development and Psychometric Evidence2018.

[20] Finn JD, S. Zimmer K. Student Engagement: What Is It? Why Does It Matter? 2012. p. 97-131

[21] Lam S-f, P. H. Wong B, Yang H, Liu Y. Understanding Student Engagement with a Contextual Model. 2012. p. 403-19.

[22] Kuh GD. The national survey of student engagement: Conceptual and empirical foundations. New Directions for Institutional Research. 2009(141): 5-20.

[23] Lev Vygotsky [Internet]. 2014 [cited March 12, 2016 www.simplypsychology.org/vygotsky.html].

[24] Quality framework: Most influential theories of learning [Internet] 2016 [cited March 13, 2016

http://www.unesco.org/new/en/education/themes/strengtheningeducation-systems/quality-framework/technical-notes/influentialtheories-of-learning/].

[25] Park YJB, Curtis J. Synchronous Learning Experiences: Distance and Residential Learners' Perspectives in a Blended Graduate Course. Journal of Interactive Online Learning. 2007; 6(3): 245-64

[26] Moule P, Ward R, Lockyer L. Nursing and healthcare students' experiences and use of e-learning in higher education. Journal of Advanced Nursing. 2010; 66(12): 2785-95

[27] Watts H, Malliris M, Billingham O. Online Peer Assisted Learning: Reporting on practice. Journal of Peer Learning. 2015; 8(1): 85-104.

[28] MacNeill H, Telner D, Sparaggis-Agaliotis A, Hanna E. All for one and one for all: understanding health professionals' experience in individual versus collaborative online learning. The Journal of continuing education in the health professions. 2014; 34(2): 102-11.

[29] McKenna L, Boyle M, Palermo C, Molloy E, Williams B, Brown T. Promoting interprofessional understandings through online learning: A qualitative examination. Nursing \& Health Sciences. 2014; 16(3): 321-6.

[30] Islam A, Salma U. The Role of Private Universities in Higher Education of Bangladesh: An Empirical Investigation. International Journal of Finance and Banking Research. 2 (4): 121-8.

[31] University Grants Commission of Bangladesh. List of Universities Dhaka: University Grants Commission of Bangladesh; 2019 [Available from http://www.ugc.gov.bd/.

[32] Nusrat M, Sultana N. Soft skills for sustainable employment of business graduates of Bangladesh. Higher Education, Skills, and Work-Based Learning. 2019.

[33] Chowdhury TA, Miah, MK. Employability skills for, entry-level human resources management positions: Perceptions of students and employers. Australian Journal of Career Development. 2016; 25(2): 55-68.

[34] Al-Masum, MA, Chowdhury SI. e-Learning for Expanding Distance Education in Tertiary Level in Bangladesh: Problems and 
Progress. Higher Learning Research Communications. 2013; 3(4): 81-91.

[35] Mahmuda M. Teaching and Learning Through Technology In Bangladesh Higher Education. International Journal of Scientific \& Engineering Research. International Journal of Scientific and Engineering Research. 2016; 7(4): 257-62.

[36] Sohail E. A digital education for a digital Bangladesh? Dhaka Tribune. 201826 January Available online at http://www.dhakatribune.com/opinion/2018/01/26/digitaleducation-digital-bangladesh.

[37] Creswell JW. Research design: qualitative, quantitative, and mixed methods approach. Thousand Oaks, California: SAGE Publications; 2014.

[38] Cohen JW. Statistical power analysis for the behavioral sciences. 2nd ed. Hillsdale, NJ. USA: Lawrence Erlbaum Associates; 1988.
[39] Elo S, Kääriäinen M, Kanste O, Pölkki T, Utriainen K, Kyngäs H. Qualitative Content Analysis: A Focus on Trustworthiness. SAGE Open. 2014; 4(1): 2158244014522633.

[40] Elo S, Kyngas H. The qualitative content analysis process. J Adv Nurs. 2008; 62(1): 107-15.

[41] Del Valle R, Duffy TM. Online learning: Learner characteristics and their approaches to managing learning. Instructional Science. 2009; 37(2): 129-49.

[42] Johnson L, Adams S, Cummins M, New Media C, Griffith U. Technology Outlook for Australian TertiaryEducation 2012-2017: An NMC Horizon Report Regional Analysis. New Media Consortium; 2012. Report No.: 978-0-9846-6015-5.

[43] Alavi SB, McCormick J. Why Do I Think My Team Is Capable? A Study of Some Antecedents of Team Members' Personal Collective Efficacy Beliefs. Educational Psychology. 2018; 38(9):1147-62. 